\title{
The effect of work discipline and work motivation toward civil servants' performance in kerenci regency population and civil registration office
}

\author{
Riswanto ${ }^{1}$, Dasman Lanin ${ }^{2}$, Syamsir ${ }^{3}$ \\ ${ }^{123}$ Universitas Negeri Padang, Padang - Indonesia
}

\begin{abstract}
This study aims to reveal the effect of work discipline and motivation on civil servants performance working at Kerinci Regency Population and Civil Registration Office, because there is a problem the employee performance it is proven by preliminary data that researchers get there are still targets that have not been fully realized. This research used quantitative method. The population of this study was all civil servants serving in the Kerinci Regency Regional Secretariat. Respondents in this study were amounted to 96 samples. The data collection technique used in this study was proportional stratified random sampling technique. The data was collected through questionnaires that have been tested of their validity and reliability in advance, both the content and empirical test items in the field. The data analysis technique used in this research was multiple regressions. The results showed that there is a significant effect of work discipline and motivation on civil servants performance working at Kerinci Regency Population and Civil Registration Office. This means that higher-level work discipline and motivation will improve civil servants performance.
\end{abstract}

Keywords: work discipline, work motivation, performance

\section{Introduction}

Public service as stipulated in Law No. 25/2009 on Public Service in Article (1) Paragraph (1) is an activity to fulfill the needs of services in accordance with the laws and regulations for every citizen on goods, services and or administrative services provided by public organizers. Subsequently reinforced in Article (7), service standard is a benchmark that is used as a guide of delivery service and quality assessment as public service obligation and a promise to society in the framework of quality, fast, easy to reach and measurable service.

The law description above provides confirmation that the government is obliged to provide the best service to the community as the recipient of the service, in accordance with the needs of the community. Services to be provided are good, easy, cheap, fast and measurable. To provide such services, it should be based on the main duties and functions of the State Civil Apparatus listed in Law No. 5/2014 on the State Civil Apparatus who served as the executor of public policy, public servants, as well as unifier of the nation. However, public service displays bad face in the eyes of society. 
This is conveyed by Secretary of Population and Civil Registry Office Kerinci Mr. Nafritman, SE, M.Si, said the bad services shown by Civil Servants or also called State Civil Apparatus seen from the service to the community are not maximal, passive towards their job, not late in completing their work. This is clearly seen as a form of low motivation and discipline of civil servants in performing their main duties and functions as state apparatus. The delay in doing the work, and there are still some employees who leave the task at work hours without a clear explanation, and often there are Civil Servants who do not come to the office for various reasons, so that their work as a public servant is not running properly.

Public service, whose employees' performance is linked to work discipline and work motivation, is the concern of the author in human resources today, for example the public service at the Population and Civil Registry Office of Kerinci Regency. The Population and Civil Registry Office of Kerinci Regency is a regional apparatus organization that spearheads local government to perform or provide services to the community. Especially on the service of population administration, it is very necessary that reliable human resources are able to do planning, administration, implementation and supervision, without the support of quality human resources involved. In order to materialize the achievement of organizational goals, it depends not only on modern equipment, facilities and complete infrastructure, but rather more on humans carrying out the work. The success of an organization is strongly influenced by the performance of individual employees. Employees' performance is not a coincidence. Many factors affect good leadership, motivation, feasible discipline improvement.

In an organization, the role and function of a leader in managing an organization greatly affects the performance of his subordinates, because a leader is a manager who plans, directs, implements and controls the performance of his subordinates. The role and function of good and democratic leadership gives employees a sense of comfort in doing their work, including in upholding the discipline. An organization will progress and succeed if the discipline of its members can be firmly and clearly applied.

Considering the position and role of civil servants based on Pancasila and the 1945 Constitution as state apparatus, the civil state apparatus is required to work professionally, disciplined, honest and responsible. A civil servant should be able to position himself as a state apparatus. Civil servants should have the motivation to work, the discipline to carry out duties and is entitled to receive compensation in accordance with applicable rules. Based on the author's observation and the description of the Secretary of Population and Civil Registry Office of Kerinci Regency, Mr. Nafritman, SE, M.Si, working for some employees of the Population and Civil Registry Office of Kerinci Regency is often done halfheartedly, unfocused, slow, long-winded, considered not a big responsibility. They work if there are leaders in office and wait for leadership orders. Many civil servants who are physically present in the office but not mentally. They fail to position themselves completely in their duties and responsibilities as state apparatuses. This has long been a negative view in society.

Looking at this reality, it is clear that work motivation, discipline and performance of the apparatus at the Population and Civil Registry Office of Kerinci Regency are very low and very disappointing for the community especially for the people who live far away. They have sacrificed the time and money to be able to take care of the demographic administration. Sometimes they come back and forth to the office but their issues have not been addressed. 
Based on above issues, the author needs to conduct a research entitled: "The Effect of Work Discipline and Work Motivation toward Civil Servants' Performance in Kerinci Regency Population and Civil Registration Office"

\section{Methods}

The method used in this research was quantitative method. The dependent variable used was performance while the independent variables were work discipline, work motivation. In this study, the operational definitions of variables are as follows:

1.Performance Variable (Y). Employees' performance is a performance that is the comparison of work achieved by employees with predetermined standards. Performance also means the results achieved by a person, both quantity and quality within an organization in accordance with the responsibilities given to him. Indicators: a) Work quality, b) Quantity, c) Effectiveness of working time, d) Attitudes and responsibilities, e) Cooperation, f) and Honesty.

2. Work Discipline Variable (X1). Work discipline is a management action to encourage the awareness and willingness of its members to comply with all rules that have been determined by the organization and social norms that apply voluntarily. The indicators are a) Obey the rules and norms, b) Responsible and perform tasks in accordance with goals and capabilities, c) Attitudes and behavior, d) Timely absence.

3. Variables Work Motivation (X2). Motivation is an impulse arising from within a person to do something and guide someone how to behave for a job or deed. The indicators are a) The driving force and desire to act to achieve goals, b) power and potential to succeed, c) Doing tasks according to the skill and ability, d) Responsibles to do things as well as possible e) The desire to cooperate productively, f) Recognition and appreciation of the effort undertaken.

In this study, the population is 125 employees of the Population and Civil Registry Office of Kerinci regency, with a sample of 96 people that were obtained using Slovin's formula. For the determination of the sample in this study, the author used stratified random sampling technique which is a sampling technique taken from each subpopulation at A random based on the proportion of the employees' rank in each subpopulation. As for getting the required data, it was obtained through questionnaire. The type of data collected in this study was taken from two sources, namely primary data and secondary data.

\section{Result and Discussion}

After getting the research results and doing the regression equation test, the author tried to explain the findings the research. The discussion of the findings in this study are as follows.

\section{The Effect of Work Discipline on Employee Performance on the Department of Population and Civil Registration of Kerinci Regency}

Based on test result of the effect between work discipline variable and performance, the author found that work discipline variable has positive and significant influence toward toward Civil Servants' Performance in Kerinci Regency Population and Civil Registration Office. This can be 
proved by the result of data processed using SPSS 18 software, that there is a significant influence between work discipline on Civil Servants' Performance in Kerinci Regency Population and Civil Registration Office with the value of $\mathrm{F}$ is 1.658 and the value of Deviation From Linierity is 0.112> 0.05. As the value of significance is greater than the Alpha (0.05), it can be concluded that the work discipline variables is linear toward performance. The amount of influence of the work discipline variable on the performance is $2.4 \%$.

Based on the result of research on the Kerinci Regency Population and Civil Registration Office, it shows that work discipline directly affects employees' performance. This is in accordance with Hasibuan's theory (2014: 193) which stated that Discipline is the awareness and willingness of a person to obey all the rules on an institution and the prevailing social norms, which will lead to good performance. The same thing is also expressed by Mudjiman, (2001: 44); Employees who possess discipline in work will produce good performance and vice versa. The relationship between work discipline and performance is also explained by Hasibuan (2007); that discipline is the sixth operative function of human resource management (MSDM). Discipline is the most important function of MSDM operative because the better the discipline of an employee, the higher quality of work that can be achieved. Based on the results of research and theories disclosed by above experts, better work discipline will be able to improve employees' performance, otherwise if the work discipline is low, it will lower the performance of employees.

\section{The Effect of Work Motivation toward Civil Servants' Performance in Kerinci Regency Population and Civil Registration Office.}

Based on the test results of the effect between work motivation and performance variables, it was found that work motivation variable has a positive and significant effect toward Civil Servants' Performance in Kerinci Regency Population and Civil Registration Office. This can be proven by the result of data processed using SPSS 18 software, that there is significant influence between work motivation on Civil Servants' Performance in Kerinci Regency Population and Civil Registration Office with F value counted at 1,594 and Deviation From Linierity) is 0,104>0,05. As the value of significance is greater than the Alpha (0.05), it can be concluded that the work motivation variable is linear toward performance. The amount of influence on work motivation variable toward performance is $2.4 \%$.

Based on the research result conducted on Kerinci Regency Population and Civil Registration Office, it shows that work motivation directly affects the employees' performance. This is in accordance with a theory expressed by Robbins, (2003: 233) that Motivation and performance have relationships with one another. Performance functions as the interaction between ability and motivation. The same thing is also expressed by Robert Kreitner and Anglo Kinicki (2001: 205) saying that work motivation can certainly affect performance, although not the only factor that shapes performance. Based on the results of research and theories disclosed by experts, better work motivation will be able to improve employees' performance, otherwise if the work motiovation is low, it will lower the performance of employees.

\section{The Effect of Work Discipline and Work Motivation on Civil Servants' Performance in Kerinci Regency Population and Civil Registration Office}

Based on the test results between work discipline and work motivation variables on Civil Servants' Performance in Kerinci Regency Population and Civil Registration Office (F test), there is a 
simultaneous significant effect between work discipline (X1), work motivation (X2) on Civil Servant's performance $(\mathrm{Y})$ at the Kerinci Secretariat Office with a significance value of $0.000<0.0$. In addition, the value of $\mathrm{R}$ Square of 0.220 can be interpreted that the two independent variables of this study have an effect of $22.0 \%$ on the dependent variable.

Based on this result, work discipline and motivation can Civil Servants' Performance in Kerinci Regency Population and Civil Registration Office and are able to influence their performance significantly. In other words, the higher work discipline and work motivation felt by employees at Kerinci Regency Population and Civil Registration Office, then their performance will be better and vice versa.

\section{Conclusions}

Based on the results of hypothesis testing to determine the effect of leadership, work motivation, compensation and discipline toward Civil Servants' Performance in Kerinci Regency Population and Civil Registration Office, it can be concluded that:

1. There is a significant effect of work discipline on Civil Servants' Performance in Kerinci Regency Population and Civil Registration Office with a contribution of $2.4 \%$. It means that work discipline can affect performance. In order get a good Civil Servants' Performance in Kerinci Regency Population and Civil Registration Office; it requires the implementation of good work discipline as well.

2. There is a significant effect of work motivation on Civil Servants' Performance in Kerinci Regency Population and Civil Registration Office with a contribution of $11.8 \%$. It means that work motivation can affect performance. In order get a good Civil Servants' Performance in Kerinci Regency Population and Civil Registration Office; it requires the implementation of good work motivation as well.

3. Work discipline (X1), and work motivation (X2) simultaneously affect civil servants' performance $(Y)$ in Kerinci Regency Population and Civil Registration Office by $22.0 \%$.

Based on above conclusions, then the author gives suggestions as follows:

1. It is recommended that the managements at Kerinci Regency Population and Civil Registration Office to pay more attention to work discipline, work motivation and job satisfaction of employees, so that their performance at can be better.

2. For further researchers, it is advisable to conduct further research related to employee performance by incorporating new theories and examining other factors that can affect employees' performance.

\section{References}

Hasibuan, Malayu S. P. 2012. Manajemen Sumber Daya Manusia Edisi Revisi. Jakarta: PT. Bumi Aksara.

Kadarisman, 2012. Manajemen Kompensasi Jakarta : Rajawali Pers 
Robbins, Stephen P. (2008). Essentials of Organizational Behavior . Edisi kesepuluh. Diterjemahkan oleh Indeks. Jakarta: PT Indeks Kelompok Gramedia.

Undang-Undang Nomor 25 Tahun 2009 tentang Pelayanan Publik

Undang-Undang Nomor 24 Tahun 2013 Tentang Perubahan Undang-Undang Nomor 23 tahun 2006 tentang Administrasi Kependudukan

Undang- Undang Nomor 5 Tahun 2014 tentang Aparatur Sipil Negara

Peraturan Menteri Dalam Negeri Nomor 76 tahun 2015 Tentang Pengangkatan dan Pemberhentian Pejabat pada unit kerja yang menangani urusan Administrasi kependudukan di Provinsi dan Kabupaten Kota

Peraturan Menteri Pendayagunaan Aparatur Negara dan Reformasi Birokrasi Nomor 15 Tahun 2014 tentang Pedoman Standar Pelayanan

Peraturan Bupati Kerinci Nomor 216 tahun 2008 tentang Uraian Tugas Pokok, Fungsi dan tata Kerja Dinas Kependudukan dan Catatan Sipil Kabupaten Kerinci 